\title{
The internationalization of local currencies of emerging countries: the experience of the Mexican Peso and the Chinese Renminbi
}

Noemi Levy ${ }^{*}$

\begin{abstract}
Globalization introduced private and structural endogenous money (private monetary debts) as the main instrument of financial capital mobilization in the international financial system. A main consequence of this feature was the internalization of emerging economies currencies unfolding two successful experiences: the foreign exchange transactions related to the Mexican peso and the Chinese renminbi. The former currency internationalized as a result of the institutional changes unfolded in the Mexican economy and it's insertion to the North American region (NAFTA); while the latter stemmed from a government strategy to influence the worldwide economy as a result of its accelerated economic growth and increased importance in the world economy. In this paper are discussed three main themes: the way in which emerging economies currencies internationalized; the insertion of these economies in the international market, and the divergent developments of successful currency internationalization.
\end{abstract}

Keywords: Emerging economies; international monetary system; currency internationalization.

JEL Classification: E44, F31, G15.

\footnotetext{
* Professor at the Faculty of Economics, Universidad Nacional Autónoma de México, Mexico City. This paper is part of the research project PAPIIT, IN IN305217, sponsored by the UNAM Research Council. The author would like to thank to the two anonymous referees of the journal for constructive comments. Obviously the usual disclaimers apply.
} 


\section{Introduction}

The currencies turnover in the international market increased rapidly in the first decade of the 21st century, involving developed and emerging countries that issue internationally-recognized money, regardless of their growth dynamics or structural imbalances. In this paper we seek to understand the reasons for the internationalization of the local currencies of emerging economies, comparing the paths followed by Latin American and Asian countries.

Our framework of analysis is based on deregulated and globalized economies, dominated by financial capital. These economies have distinguished themselves by deploying export-led neo-mercantilist models, with an unbalanced current account, in a context of high international capital mobility, and increasing participation of foreign investment (direct and portfolio) in external financial accounts.

To this must be added the fact that the international financial market is dominated by private debts, under the aegis of a unit of international value (US dollar), which has allowed great liquidity in international currency for developing countries. This process unfolded in a context of acceleration of the financial market, in which the global exchange market reactivated to guarantee access to US dollars. This process created financial instruments that neutralize the risks arising from changes in interest rates, exchange rates and prices of goods and provided liquidity in the international unit of accounts which, nevertheless, are not exempt from financial instability or speculative activities.

In this condition, the Mexican peso and the Chinese renminbi internationalized; the Brazilian real tried but failed to complete this process; and the Chilean peso did not even begin the process. From our perspective, the currencies that successfully internationalized reflected two models. The Chinese renminbi went through this process in a relatively short period, in a context of growing economic activity, current account surplus, and its objective was to have greater weight in the international financial market. On the other hand, the internationalization of the Mexican peso responded to the insertion of Mexico into the North American region, which generated reliability, despite the structural current account deficit, causing an excessive increase in liquidity, which resulted in growing instability and the neutralization of the Bank of Mexico's anti-cyclical policies. The Brazilian real did not succeed in internationalizing because it failed to position itself as a regional power, which was its strategic goal within the context of the Southern Cone; meanwhile, as is said above the Chilean peso never had that intention.

This paper consists of five sections. After the introduction, the bases for the internationalization of the local currencies will be explained in brief, followed by a section discussing the financial and productive characteristics of the countries that have experienced the greatest internationalization of their currency. The fourth section analyzes the characteristics of the transactions made using the internationalized currencies and the performance of their local markets, and relates these to the variables of production. In the final section, a summary of the conclusions is presented. 


\section{The internationalization of emerging currencies in the period of financial capital dominance}

The volume of liquidity is related to the motives of money demand, economic dynamics and the financial institutional arrangements of the dominant economic model, where the organization of the payments system, especially in the international level, is of outmost importance.

One of the theories of financing states that banks have the ability to issue loans intended to cover the liquidity needs of working capital (wages), which returns to the productive apparatus via the purchase of goods and services - motive of transaction, (Sawyer, 2016; Seccareccia, 2003, 2013; Bossone, 2003; Graziani, 2003), and the sale of fixed assets (intermediate and capital) are financed by retained earnings from previous periods (Kalecki, 1971), which are subject to financial intermediation in the capital market and, can be used to speculative activities, particularly in periods of financial capital dominance (Keynes, 1936).

Capital markets have the function of generating liquidity and most importantly they distribute profits among capitalist agents, which is of utmost importance under conditions of financial capital dominance. The functioning of capital markets is explained through several theories that comprise the Liquidity Preference (Keynes, 1936); the Financial Instability Hypothesis (Minsky, 1986), and Financial Inflation (Toporowski, 2000). In the famous chapter 12 of his General Theory (1936), Keynes argues that the capital market is speculative by nature and its operations must be limited, especially in developed financial centers. Minsky (1986), in the light of the price movement of financial assets, indicates that the capital market generates the necessary liquidity but it is inherently unstable, from where follows that economic cycles (booms and bust) is a structural characteristic of capitalist economies. As a result, he emphasizes the need to regulate the provision of credit during boom times and guarantee liquidity in the debt market during periods of recession. With reference to financial cycles, Toporowski (2012) points out that large corporations engage in treasury activities that generate over-capitalization (sub-capitalization) via the trading of financial securities, regardless of the value of the assets and outstanding commitments, from which they obtain financial gains (or losses), thereby large corporations financial activities are unrelated to productive investment expenditures.

Historically, the 1970s marked the beginning of the second phase of globalization, in which financial capital turn to be dominant, with the particularity that money became independent of commodities. The demonetization of gold altered the international payment system and the functioning of the banking and the non-banking financial sector. Capital movement controls were removed, financial flows rocketed, capital market were activated and linked to the global financial market. In this context, central banks were unable to control the money supply, limiting themselves to determining the interest rate (Blinder, 1998), not being able to fully perform the function of lender of last resort. For the first time, endogenous 
money dominated the international financial market, ${ }^{1}$ and credit issuance globalized, (Borio et al., 2015).

Thus, the international market was driven by private monetary debts (bank deposits), subject to being convertible into international reserve units. In this context, financial capital acquired relative autonomy from productive capital (Russell, 2008), laying the foundations of the domination of financial capital over the social relations of production, unfolding a process of financialization, which Epstein, $(2005$, p.4) defines as "the increasing role of financial motives, financial markets, financial actors and financial institutions in the operation of domestic and international economies". Under these conditions, the exchange rate is detached from trade flows, and becomes dependent on financial flows (direct and portfolio foreign investment), and is highly responsive to short-term financial flows (Harvey, 2009).

The high level of international liquidity and the deepening of the financial markets rendered obsolete conventional theories of international trade, built on the assumptions of perfect competition and price arbitration, with the result that neither exchange rates (whether fixed or flexible) nor interest rates managed to match returns and prices in the different economies. ${ }^{2}$

In this context, is revived the idea that developed countries, especially those that issue international money, can extract returns from backward economies. Eclac (1949) formulated this approach as a central argument for the deployment of industrialization policies in Latin America, via the theory of unequal exchange, which was explained on the basis of unequal productive structures between developed and developing countries. From this perspective, industrial countries are technological innovators, which enables them to develop oligopolistic structures that can determine prices of their own goods, as well as of the primary resources produced by the backward economies. Under this framework, backward economies are "pricetakers" and are subject to economic cycles, which in the boom phase increase the price of exportable raw materials, improve the terms of trade, and increase the availability of international credit. Taken together, this expands the growth of the backward economies. Conversely, a drop in the prices of raw materials leads to a deterioration in the terms of trade, a fall in external financing, a crisis in the balance of payments and a decline in production activity. The peculiarity of this process is that the benefits obtained in the boom phase are lost

\footnotetext{
${ }^{1}$ The heterodox position that supposes that money is structurally endogenous, while the assumption of non-neutral has not achieved consensus within economic theory. The Wickselian assumption about the endogeneity of money is revived through the Taylor rule, adopted by the new classical consensus (Blanchard, 1998) which substitutes the LM curve for the interest rate and, based on the limitation of supply side of the economy, it is assumed that the expansion of (public) spending above a "natural" level generates inflationary pressures and unemployment.

${ }^{2}$ International arbitration did not provide exchange rates that equated the prices of a commodity (basket of goods) in different economies, nor currencies that had the same purchasing power in the different economies (Krugman and Obstfeld, 2006). The optimal currency area theory (Mundel, 1961) has not worked either. According to this theory, under certain economic conditions a common currency can avoid distortions due to deficiencies in (or the absence of) arbitration in the exchange rate or the interest rate.
} 
in the recession phase, explained by the price inelasticity of the demand for imports and exports. $^{3}$

Historically, between 1940 and 1980, Latin America went through a period of industrialization by import substitution, which was reversed in the 1980s (Rodrik, 2015). The export-led economic models, specializing in raw materials, reappeared (Moreno-Brid and Garry, 2015) in a context of growing structural imbalances in the current account; this generated a process of opening up to capital, dominated by growing short-term investment flows.

The novelty of the export-led economic model is that emerging countries became globalized and financial markets expanded, dominated by short-term investments flowsfinancial portfolio investment, and the credits issuance was transferred to the international private sector, in a context of growing structural imbalances in the current and capital accounts, with inefficient and dysfunctional arbitrage processes, alongside volatile exchange rates and interest rates.

As a result of these conditions, there is an increase in the activity of the currency exchange markets that, on one hand, seek to reduce the financial risks that are taken on by private agents (Eatwell and Taylor, 2000) and, on the other, become transmitters of financial instability to other economic spaces and susceptible to financial speculation by institutional investors and large corporations.

The organization of the international financial system was altered despite the fact that its operation was maintained on the basis of a dual system that combined currencies that operate as international reserves, and the "other currencies". The peculiarity of this organization is that the US dollar (which retains its character as an international reserve currency) is not limited by any commodity, and nor does it operate on the basis of surplus current accounts. On the contrary, the United States is the main generator of the current account deficit by taking on the function of the engine of global demand, which according to Minsky (1989) provide liquidity to the international market. On this account is argued that the United States economy, in its capacity of issuing the unit of international of account, expropriates yields from the rest of the world, because it determines the productive structures of the other economies and regions (De Cecco, 2012).

Developed countries that don't issue global reserve currencies, and emerging economies (with the exception of Latin America) became the providers of goods and services on the international market with structural surpluses of their current accounts, which reduced production costs, specifically low labor costs, increasing the profits of large transnational corporations (De Cecco, 2012). In addition, the hegemon (United States) is the main recipient of financial flows, which allowed it to deepen and strengthen its capital markets and strengthen its role as a global financial center and guardian of international value.

The "other currencies" that circulate along with the global reserve currency assume the particularity that in this period they can operate as assets, if they acquire the status of

\footnotetext{
${ }^{3}$ Based on the Theory of Unequal Exchange, ECLAC proposed an Import Substitution Industrialization (ISI) to achieve economic independence and "reach" the backward countries.
} 
convertible currencies on the international market, with respect to the world reserve currency. Thus, as was said before, financing is internationalized through the conversion of local monetary debts (bank deposits in the domestic currency) into the international reserve currencies. ${ }^{4}$ Specifically, credits grant access to purchasing power via the generation of a means of payment widely accepted on the international market, in a reserve currency or convertible currencies.

In this scheme, banks determine the direction of financial flows, while non-banking financial institutions generate rights that are associated with the credit risks of companies (Borio et al 2015, p.15). Financing is defined as "assuming liabilities and acquiring rights" (Avdjiev, 2015, p. 6) that, in a global financial system, are generated in different economic spaces, independently of production, and of the position of current accounts. This process was described as follows:

"Let us take the concrete instance of a US branch of a global European bank that borrows dollars from a US money market fund and then lends dollars to an Asian firm through its Hong Kong branch. The bank may have its headquarters in London, Paris or Frankfurt, but the liabilities on its balance sheet are in New York and the assets on its balance sheet are in Hong Kong SAR. No mapping relates the balance of this bank to an area of generation of gross domestic product, or a component of GDP within a productive area" (Avdjiev et al., 2015, p.6).

There are many ways in which payments are made worldwide, of particular note being the round-tripping model that supposedly sees funds exit and re-enter economies, without being noticed in external accounts, ${ }^{5}$ and pure offshoring schemes that involve national currencies outside the issuing economies. ${ }^{6}$ They can also take the form of "asset swaps" that take place in units of international reserve to settle debts or diversify portfolios. ${ }^{7}$ In this context, the reserve currencies are not only treated as international reserve units, but also operate as "settlement currencies" insofar as the final payments are made in US dollars, regardless of whether any party in the transaction (lender - borrower or seller - buyer) is actually located in the United States (Avdjiev et al., 2015, p.15).

\footnotetext{
${ }^{4}$ The international financial market makes it clear that savings are a real variable linked to the system of national accounts, separated from the credits that form financial flows, while investment depends on financing. Specifically, the credits grant access to purchasing power via the generation of a means of payment widely accepted on the international market, in a reserve currency or currencies convertible into reserve currency.

${ }^{5}$ The example that is used is that the deposits of the residents of the United States flow offshore (extraterritorial market) and are returned to the United States via a loan that provides credit to the residents of the United States, which does not appear in the balance of the current account because the outflows are equal to the inflow of capital, that is, they have no impact on the net flows. However, this is a highly unstable scheme and played a crucial role in the US sub-prime crisis (Avdjiev et al., 2015, p.9)

${ }^{6}$ A typical transaction for an offshore market in an international currency is denominated in that currency, takes place between non-residents, outside the country of issue of the currency, and is subject to the laws of a different political jurisdiction. This type of transaction is not necessarily recorded in the current or capital account of the country issuing the local currency, although it is typically balanced and settled via the banks of the issuing country.

${ }^{7}$ It is a symmetrical exchange of rights between a pair of gross flows of rights that can be in the form of dollars between two agents that are resident in different countries, emphasizing that in this case it is not necessary that the funds be either obtained or used in the United States (Avdjiev et al., 2015 p. 9).
} 
Then, cross-border transactions are made in international currencies (always convertible on the world market) but the final payment takes place in global reserve units (US dollars), without the presence of any resident of the United States. In turn, the expansion of liquidity in international reserve units is not achieved by issuing US banknotes, but in the form of dollar-denominated loans that are generally directed towards companies and governments of the "smaller and poorer countries, because the richer and larger economies can finance their needs with domestic debt rather than external loans" (Toporowski, 2017, p.124). In addition, local currencies access reserve units if they have the ability to internationalize or acquire the status of international assets. The great difference with international currencies that are not reserves is that they must be converted into dollars and do not operate as units of account, and even less as currencies for liquidation.

We can conclude by pointing out that the international financial market provides financing to financial and non-financial corporations and governments, to expand production and accumulation and refinance debts. This implies a growth of debts over production, converting the liabilities of one currency into another (to access US dollars), and extending the timeframe of debts, which can reduce the cost of financing and provide long-term liquidity. These operations can alleviate external liquidity constraints, but are subject to great financial instability, such that not all credits respond to speculative activities, while refinancing activities are not free of instability or crisis (Toporowski, 2017). This affect above all emerging countries that are highly dependent on international loans denominated in US dollars, and can access through the international market to almost unlimited international reserves of countries, with highly convertible currencies. The main limitations of this new arraignment is that the financial market becomes an important source of growing instability since is depends on the international context and the temperament of international investors.

\section{An examination of emerging economies insertion in the world economy during the financialization era}

Following deregulation and globalization of the capitalist system, the emerging economies of Latin America and Asia adopted an export-led model, opening-up their capital account, at different speeds and depths (Stallings and Studart, 2006). In Latin America, this model was based on the re-primarization of the external sector (Moreno-Brid and Garry, 2015) with some exceptions (Mexico), and it developed as the result of the breakdown of the industrialization process by import substitution (Rodrik, 2015) which led to an acceleration of imports. This occurred even in Mexico, with its specialization in export manufacturing. For its part, China specialized in export manufacturing, combined with rising fixed capital expenditures, accompanied by surpluses in the current account.

In Latin America in particular, the coefficient of exports in output was the most dynamic income activity, without activating expenditure in fixed investment, leading to the first great paradox, which gave rise to a productive organization based on assembly processes with reduced added value, which tied Latin American industry to the simplest strata of global production chains (Levy, 2018). Another important aspect is that the commercial balance of trade in raw materials was responsible for generating surpluses in foreign trade or, in the case of Mexico, partially neutralizing the trade deficit, which was maintained by price bubbles 
around raw materials (Ortiz, 2016). For its part, China's development was based on manufacturing exports, succeeding in making its production processes more complex and scaling them up towards more sophisticated strata of international value chains, in a context of increasing accumulation spending, ensuring continual and growing surpluses in the current account.

This analysis of the Latin American region is made with reference to Brazil, Chile and Mexico, which contrast with the evolution of the Chinese economy. An initial characteristic is the substantive difference in the composition of production expenditure among the countries concerned. Brazil, Chile and Mexico have a significantly higher consumption coefficient, with a reduced share of gross fixed capital expenditure in output, with relatively low levels of economic growth, although exports with respect to output grew significantly, presenting different results in the trade balances: deficit in Mexico, surplus in Chile and mixed in Brazil, which as a whole deteriorate after the Second Global Financial Crisis (GFC). On the other hand, China has an expenditure structure that is based on fixed investment with relatively low consumption coefficients and a surplus in the trade balance. From the above it can be deduced that the Chinese economy would be more integrated than the Latin American ones (Figure 1).

Figure 1. Gross Domestic Product structure (\% in terms of GDP) and trade balance

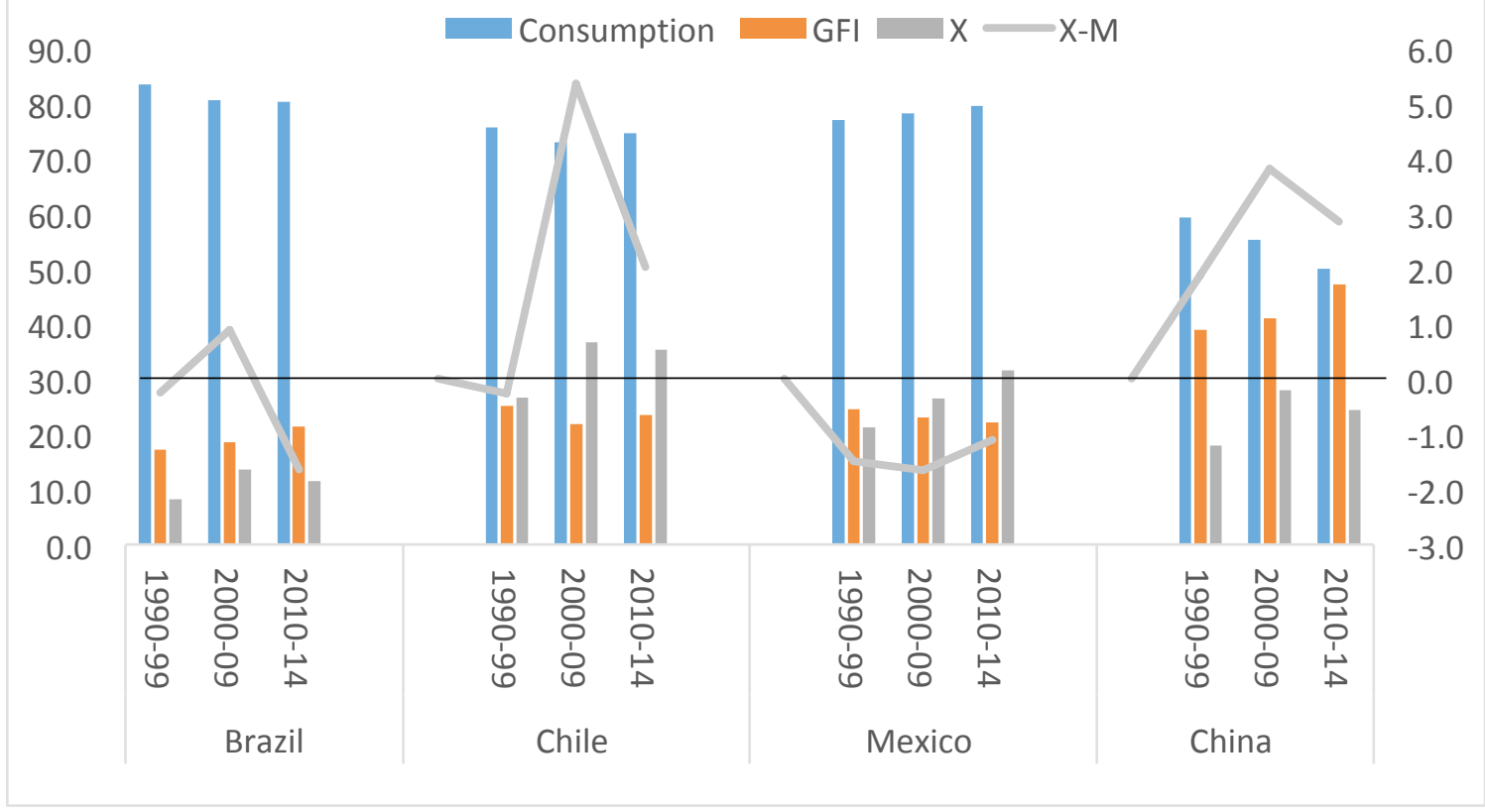

Obs.: trade balance is measured in the left axis; GFI: Gross Fixed Investment; X: export, M: imports Source: Own calculation based on Word Bank data

An important feature in terms of commercial openness is the composition of the trade balance. Chilean exports were led by raw materials with a smaller share of manufactured goods; Brazil has a more balanced export sector between manufactured goods and raw materials, which broke down between 2010-14; while Mexico was dominated by manufacturing exports that, since the 1980s, 'de-petrolized' the commercial account; and Chinese exports were led by manufacturing exports (Table 1). The surpluses of Chile and Brazil are therefore explained by the inflation of raw materials prices, which negatively affected China, while in Mexico the increase in the price of oil reduced the deficit of the trade balance. 
Another distinctive factor in the commercial openness of the Latin American countries is that their imports are very high, and there is a growing liberalization of trade in terms of production. Among the countries analyzed, Chile has the most open economy, followed by Mexico and China, with Brazil remaining the comparatively more closed economy (Table 1).

Table 1. Commercial opennes and export structure, on terms of GDP (\%)

\begin{tabular}{l|cccc|cccc}
\hline & $1983-89$ & $1990-99$ & $2000-09$ & $2010-2014$ & $1983-89$ & $1990-99$ & $2000-09$ & $2010-2014$ \\
\hline & \multicolumn{5}{|c|}{ Mexico } & \multicolumn{5}{c}{ Chile } \\
\hline$X+M$ & 32,0 & 39,8 & 51,7 & 61,8 & 53,9 & 54,7 & 67,9 & 67,9 \\
$X$ & 19,9 & 20,5 & 26,2 & 31,6 & 28,6 & 27,6 & 37,2 & 35,0 \\
$X_{\text {Prim }}$ & 8,9 & 4,0 & 5,2 & 7,2 & 21,1 & 18,0 & 26,3 & 25,8 \\
$X_{\text {Man }}$ & 4,7 & 12,9 & 19,1 & 22,3 & 1,9 & 3,1 & 4,7 & 4,1 \\
\hline \multicolumn{8}{|c}{ Brasil } \\
\hline$X+M$ & $\mathbf{1 8 , 2}$ & $\mathbf{1 5 , 4}$ & $\mathbf{2 5 , 0}$ & $\mathbf{2 3 , 3}$ & 24,8 & 32,9 & 49,5 & 48,5 \\
$X$ & $\mathbf{1 0 , 9}$ & $\mathbf{7 , 7}$ & $\mathbf{1 3 , 4}$ & $\mathbf{1 1 , 1}$ & 11,8 & 17,5 & 27 & 25,7 \\
$X_{\text {Prim }}$ & $\mathbf{5 , 5}$ & $\mathbf{3 , 1}$ & $\mathbf{5 , 7}$ & $\mathbf{6 , 1}$ & na & na & na & na \\
$X_{\text {Man }}$ & $\mathbf{4 , 7}$ & $\mathbf{3 , 8}$ & $\mathbf{5 , 9}$ & $\mathbf{3 , 3}$ & na & na & na & na \\
\hline
\end{tabular}

Obs. X+M: commercial openness, $\mathrm{X}$ : exports: Xpri: Exports in primary products, $\mathrm{X}$ man: Exports in manufactured goods, na: not available

Source: Own calculation based on ECLAC and World Bank data

A second feature of this model is the financial liberalization, which took place at different speeds and depths, with high volumes of capital entering Latin America, particularly Brazil, Chile and Mexico, above the financing needs of the current account (Figure 2). Based on the above, we can assert that financial flows became relatively independent from the current account; while in China the inflow of capital was lower due to the regulations that accompanied the liberalization of the financial process, which, together with the growing expenditure of gross formation of fixed capital, made it possible to deploy more financing denominated in the local currency. Thus, financial liberalization of countries in Latin America increased their position as debtors ahead of China.

Examining the composition of the liabilities on the financial account reveals the presence of drastic changes in the volume and composition of financial flows. Foreign direct investment and portfolio investment displaced "other investments," where credits are located (Figure 3). Second, in Latin America, portfolio foreign investment acquired great dynamism, especially after the 2008 crisis, while China maintained greater control over its financial account. In Latin America, Chile was the largest recipient of FDI together with Mexico, followed by Brazil which saw increased FDI in the 2000s. On the other hand, portfolio investment flows are higher in Chile and Mexico compared to Brazil. Meanwhile, the Chinese economy is mainly a recipient of $\mathrm{FDI}$, in the context of greater state regulation, which obliges the transnationals to transfer technology and links their production with the local economy (Chang and Grabel, 2004), with a low participation of foreign portfolio investment (Figure 3). 
Figure 2: Balance of Payment Indicators (\%) terms

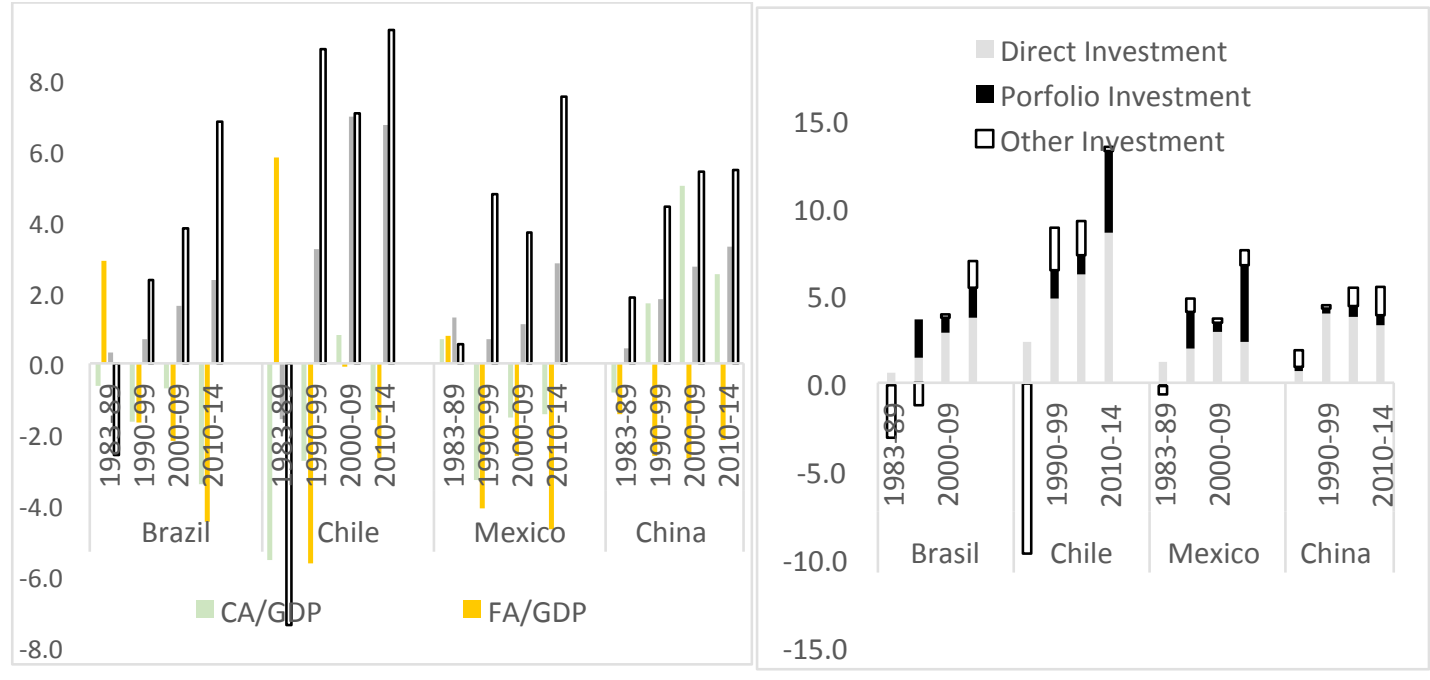

Figure 3: Financial Account composition in of GDP, (\%)

Obs. CA: Current Account, FA: Financial Account, GDP: Gross domestic Product Source: Own calculation base on IMF and World Bank data

Finally, the opening up of the capital market transformed the financial systems of Brazil, Chile and Mexico (we have no figures for China) moving towards a financial structure that strengthened the debt and capital market; the growth of the debt market in Brazil was very noticeable, while Chile maintained a relatively strong banking sector and a significant deepening of the stock market. Meanwhile, Mexico had a relatively small financial market in relation to the other countries (Figure 4), which as will be seen in the next section is due to the insertion of the Mexican financial system in the North American.

Figure 4. Financial Market size and composition in terms of GDP

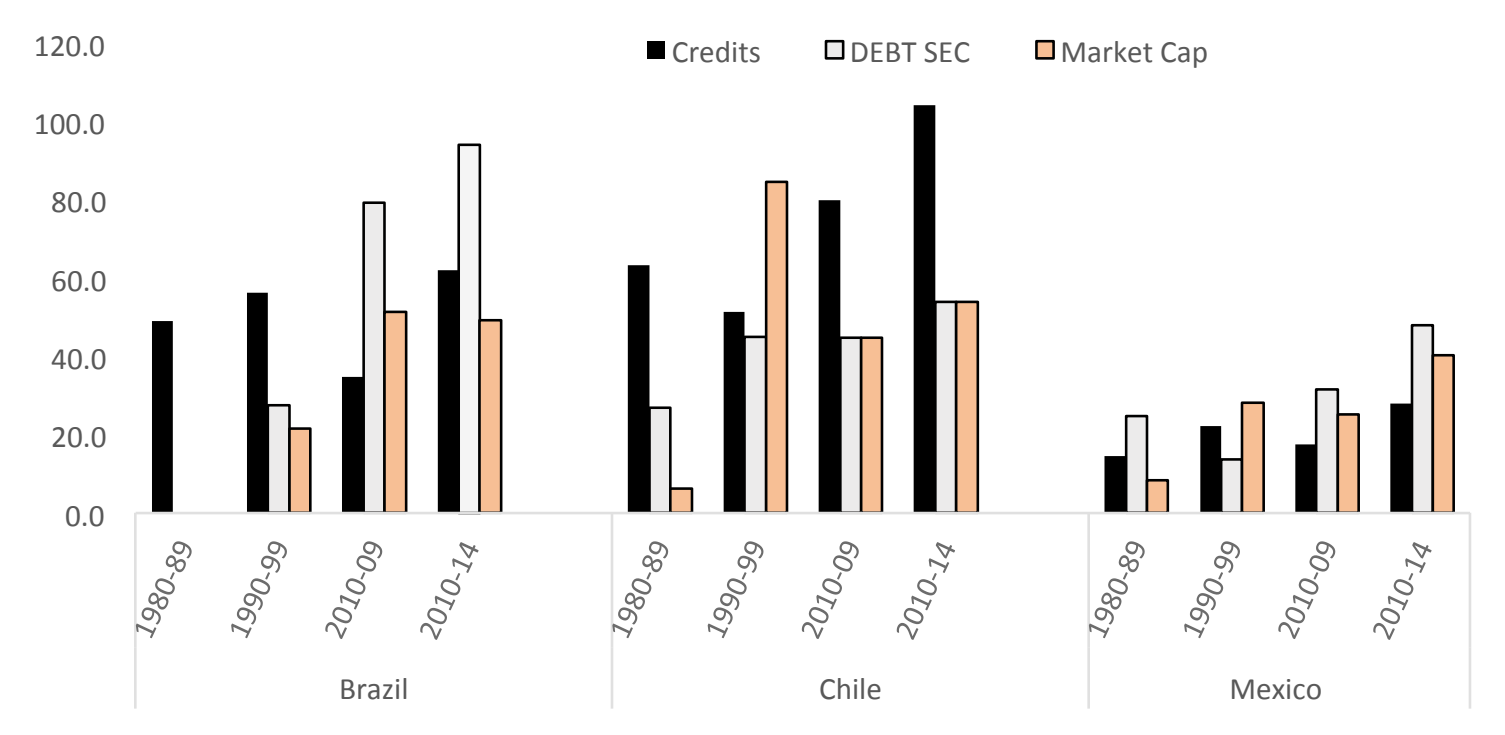

Obs.: DEB SEC: Bond market: Market Cap: market capitalization

Source: Own calculation based on Word Bank data (GDP), BIS statistic explorer (debt securities) and IMF data (credits).

From the above discussion can be concluded that Latin America countries, particularly Mexico, can be differentiated from China, in terms of the commercial and financial insertion to 
the world economy. The economic structure of Latin America unfolded a deindustrialization process while China increased its investment coefficient in GDP and underwent a process of industrialization, with smaller economic openness in China (export plus imports in relation to GDP) in comparison to Mexico and Chile.

In the financial sector, Latin America lifted all capital controls in a very short period, opening up the external financial account in a short period; becoming highly dependent on external direct and portfolio investment, while Asia, and specifically China, had a slow process of financial capital liberalization, state regulated, which created finance in local currencies, thereby less dependent in terms of financial flows.

\section{The currency market in emerging countries: divergent developments}

The foreign exchange market became an important access channel to international units of accounts, especially relevant for emerging economies, whose main activity takes place in the international market, as a result of the increased external trade (exports), reliance on foreign credits and recipient of foreign capital flows, all denominated in dollars. Forex activity can also be related to multinationals corporation balance sheet diversification, linked to speculative activity, moreover completely unrelated to the economies in in which Forex instruments are denominated. Therefore, the internationalization of domestic currencies through foreign exchange transactions is double-folded since, on one hand it reduces risk providing liquidity in foreign currency in specific prices and, on the other set off speculation that can be unlinked to the activities or agents of the economies in which Forex are denominated.

In this context is discussed the global foreign exchange transactions that are measured through the average daily turnover volume of the foreign exchange market, net-net basis. ${ }^{8}$ The data shows that at the global level the total currency turnover accelerated over the first decade of the 21st century; doubling of the average value of total daily global exchange between 2004 and 2007, and again between 2007 and 2013, with a slight deceleration in 2016 (Figure 6). Worldwide, foreign exchange and interest rate swaps and spot transactions dominate, with fewer outright forward transactions that, as a whole, make up traditional transactions, and small increases in the number of options (Alcala et al., 2014).

In this scenario, there has been an acceleration in transactions in the currencies of emerging countries. Particularly, Forex transactions based on the Mexican peso followed global trends with a rapid acceleration from 2001, taking the lead among emerging currencies worldwide. The Chinese renminbi also followed this path, albeit belatedly (2010), displacing in 2016 the pole position of the Mexican peso among emerging countries; the Chilean peso did not internationalize; while the Brazilian real sought to internationalize without achieving its objective (Figure 5).

\footnotetext{
8 The measurement on the net-net basis discounts the duplication of local and cross-border transactions, which allows the liquidity of currencies to be measured globally (see BIS, 2016).
} 
Figure 5. Total Forex, and Forex related to Mexican peso, Brazilian Real, and Chines Renminbi, and type of transactions (thousands of millions US dollars, average daily turnover)

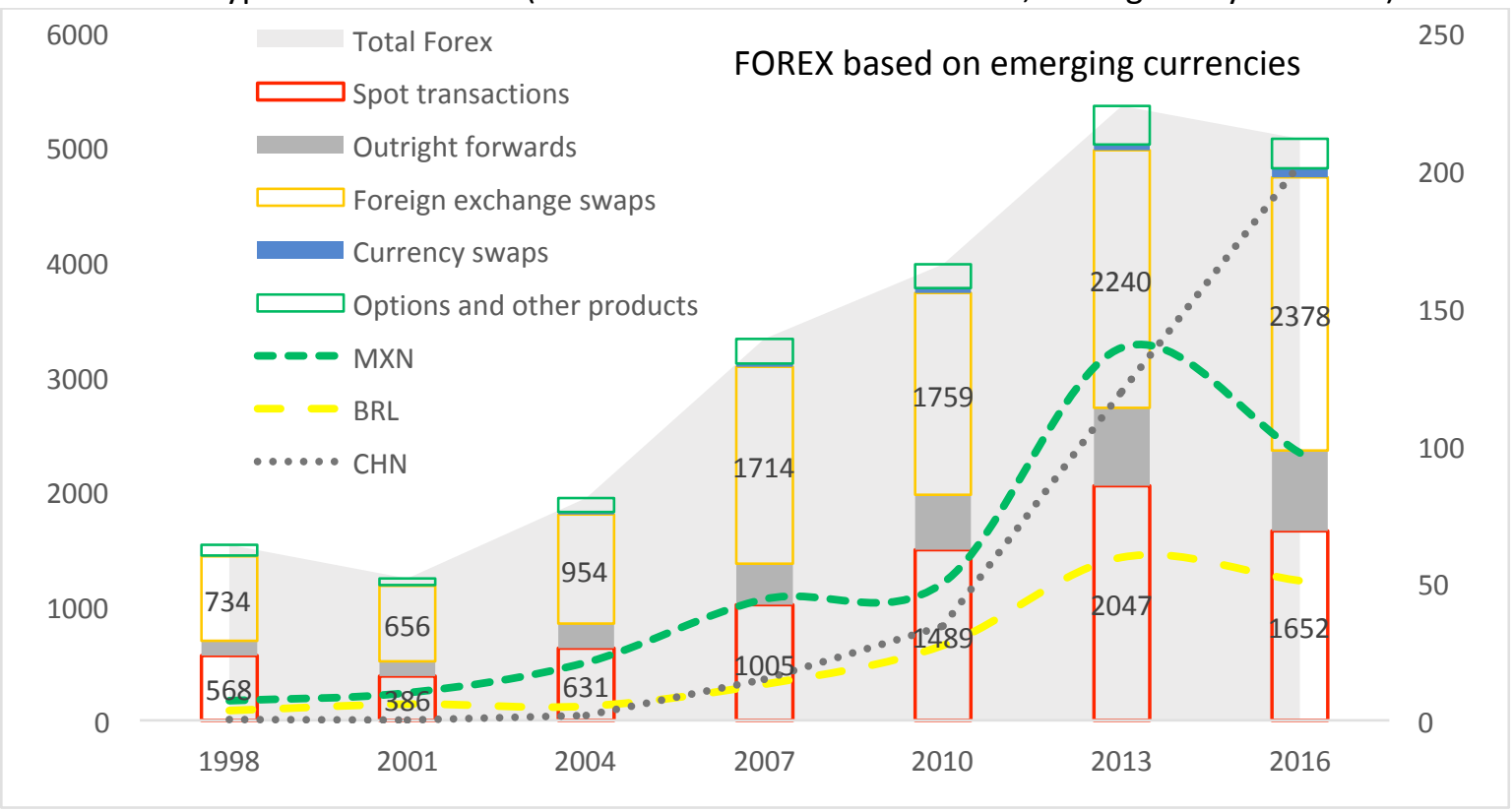

Obs. MXN: Forex related Mexican peso, BRL: Forex related the Brazilian Real; CHN: Forex related to the Chinese renminbi. Calculation net-net based.

Source: Own calculation on data of BIS $(2001,2004,2007,2010,2013,2016)$.

The different composition of the instruments used in the internationalization of the currencies of emerging countries is of note to highlight the increased negotiability of emerging countries currency. Transactions related to the Mexican peso followed a pattern similar to the US dollar, led by spot transactions and exchange rate and interest rate swaps, followed at some distance by outright forward instruments, currency swaps and options. The Brazilian real had a different behavior insofar as simple term instruments dominated (outright forward), followed by spot transactions, options, with a low proportion of interest rate and exchange rate swaps. Meanwhile, transactions relating to the renminbi resemble the composition of the Brazilian real due to the importance of outright forward transactions, even though these show a downward trend, and share with the Mexican peso the growing participation of exchange rate and interest rate swaps, and the proportion of spot transactions (Figure 6).

Kaltenbrunner (2011, p.124-125), based on interviews with currency brokers in emerging countries, points out that the growing share of forward transactions is carried out offshore, and involves non-deliverable forward contracts that differ because once these contracts mature they are settled in other currencies (usually US dollars) because the local currency is "not deliverable," that is, it is not an efficient international asset. Kaltenbrunner (2011), citing Libscomb (2005), points out that this is a strategy followed by international banks to take positions in emerging markets; adding that between $60 \%$ and $80 \%$ of these operations were used in installment contracts (speculative interests) with heavy participation by international hedge funds. An additional fact is that "non-deliverable" forward contracts have operated strongly in almost all of Latin America (that considers the Chilean and Argentine peso, Colombian peso, Guatemalan quetzal, Peruvian nuevo sol, Uruguayan peso and Venezuelan bolivar) and Asia, with the Chinese renminbi, Indian rupee, Korean won, among others (Libscomb, 2005), which are distinguished by their association with relatively closed 
markets. Thus, at the international level, the Mexican peso is very negotiable and the Chinese renminbi has become an international asset.

Figure 6. Forex Transactions by instruments, in term of total Forex by currency (\%), calculation net-net based

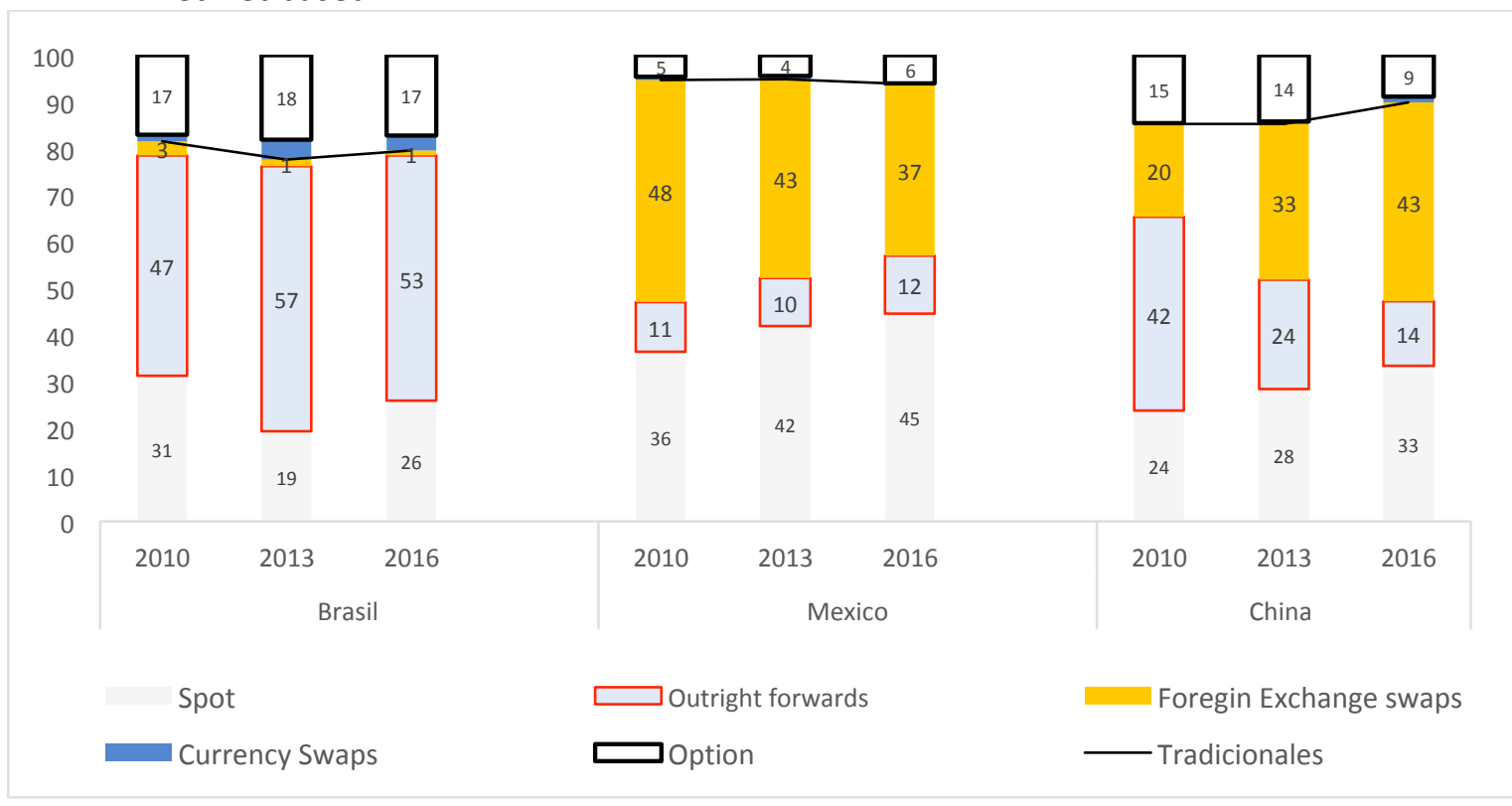

Source: Own calculation based on data of BIS $(2010,2013,2016)$.

Analysis at the level of institutional counterparts offers interesting elements that shows the difference between the Latin American currencies and the Chinese renminbi. The "other financial institutions" stand out in the operations with the Brazilian real, composed of pension funds, insurance companies, money market funds, etc., which are medium-sized institutions, with limited participation by informant dealers; ${ }^{9}$ transactions related to the Mexican peso also dominate the "other financial institutions" and informant dealers are increasingly prevalent, which is explained by the strong presence of transnational corporations in the Mexican financial system, particularly in the banking sector (Levy and Dominguez, 2016). The institutional counterparts of the transactions related to the Chinese renminbi are the informant dealers, with the peculiarity that the government exerts greater control over the Chinese financial system, with relatively lower participation by the "other financial institutions." Meanwhile, non-financial customers have a greater presence in transactions related to the Brazilian real, applying the same as to the Chinese renminbi, with the exception of 2016, when it becomes the most important international asset among emerging countries (Figure 7).

The measurement of the liquidity of the currencies from the counterparts of the transactions by location involves local and cross-border transactions, with cross-border transactions dominating in the case of the Mexican peso, which is less noticeable in the case of the Brazilian real and the Chinese renminbi, where there is greater participation by local

\footnotetext{
${ }^{9}$ This group is composed of commercial and investment banks and insurance companies that participate in the broker market -inter-dealer market, and operates with large clients, buys and sells currencies and operates with derivatives.
} 
counterparts (Figure 8). This demonstrates the internalization of the Mexican peso in the world market.

Figure 7: Forex by institutonal counterparties in term of total currency, forex, base net-net (\%) net (\%)

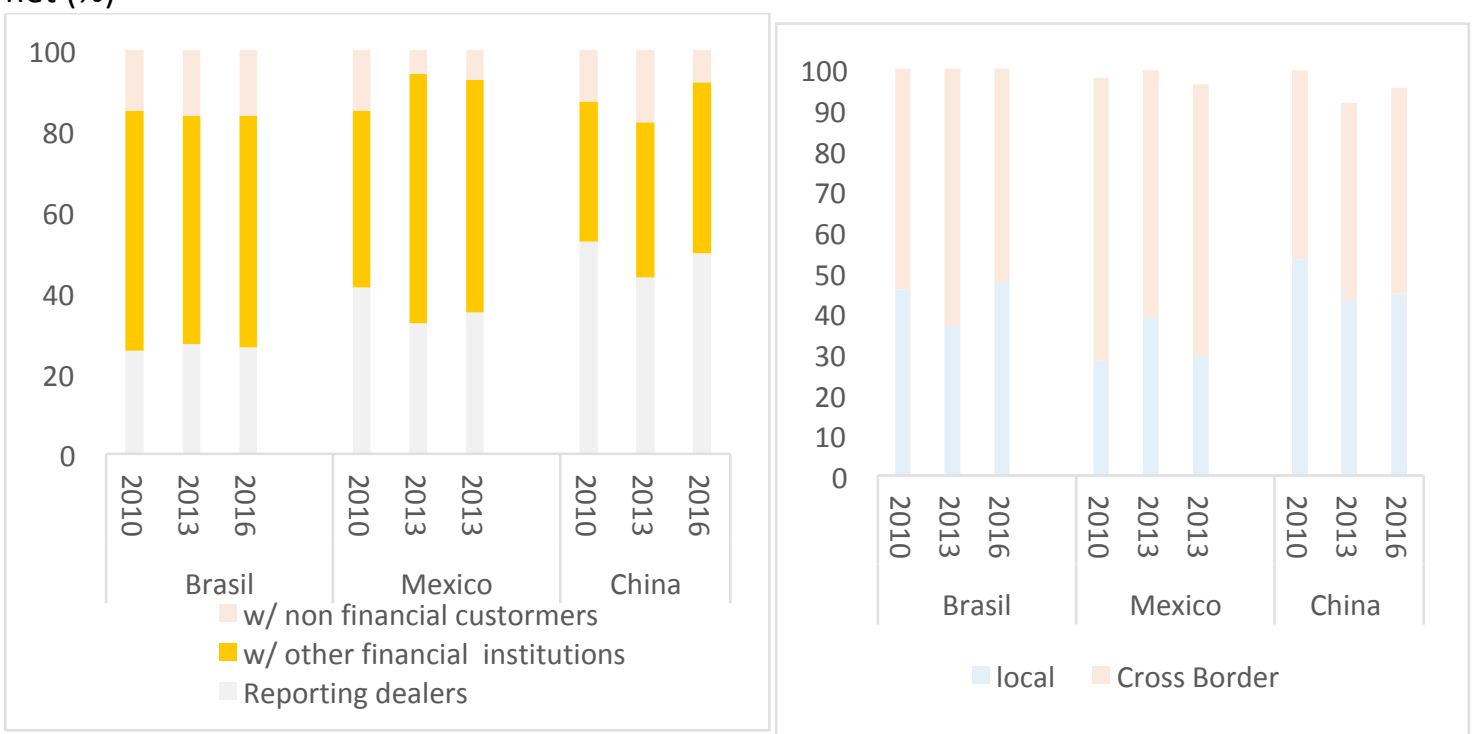

Source: Own calculation based on data of BIS 2010, 2013, 2016.

A further comparison is the evolution of the transactions measured from the individual countries (gross-net base, which only deducts duplications out local counterparts) that is compared with the behavior of the transactions at the global level (net-net base) to determine volume of Forex transactions by currencies. The order of precedence, views of the exchange transactions from the global perspective, is headed by the Mexican peso, followed by the Chinese renminbi (which displaces the Mexican peso in 2013), the Korean won, the Brazilian real and, in a distant place transactions related to the Chilean currency (Figure 9).

However, the transactions aggregated by country (gross-net basis) show that the financial centers in the Asian countries are much larger, notably as of 2007, led by the Chinese exchange market, followed by the Korean market and the Indian market. In general, the exchange transactions related to the financial centers of Latin America are smaller, with large shares of some currencies as international value assets (Figure 10).

At the level of the domestic financial centers (gross-net measurement), the composition and localization counterparts (local and cross-border) are quite indicative. In Latin America and Asia, local counterparts dominate, with the exception of Mexico, where crossborder transactions are more important, which resembles to integration of the Mexican financial markets to the North American region. In other words, the internationalization of the Mexican peso was coupled with a domestic exchange market that was significantly reduced (Table 2). 
Figure 9: Geographical distribution Forex -net base transactions

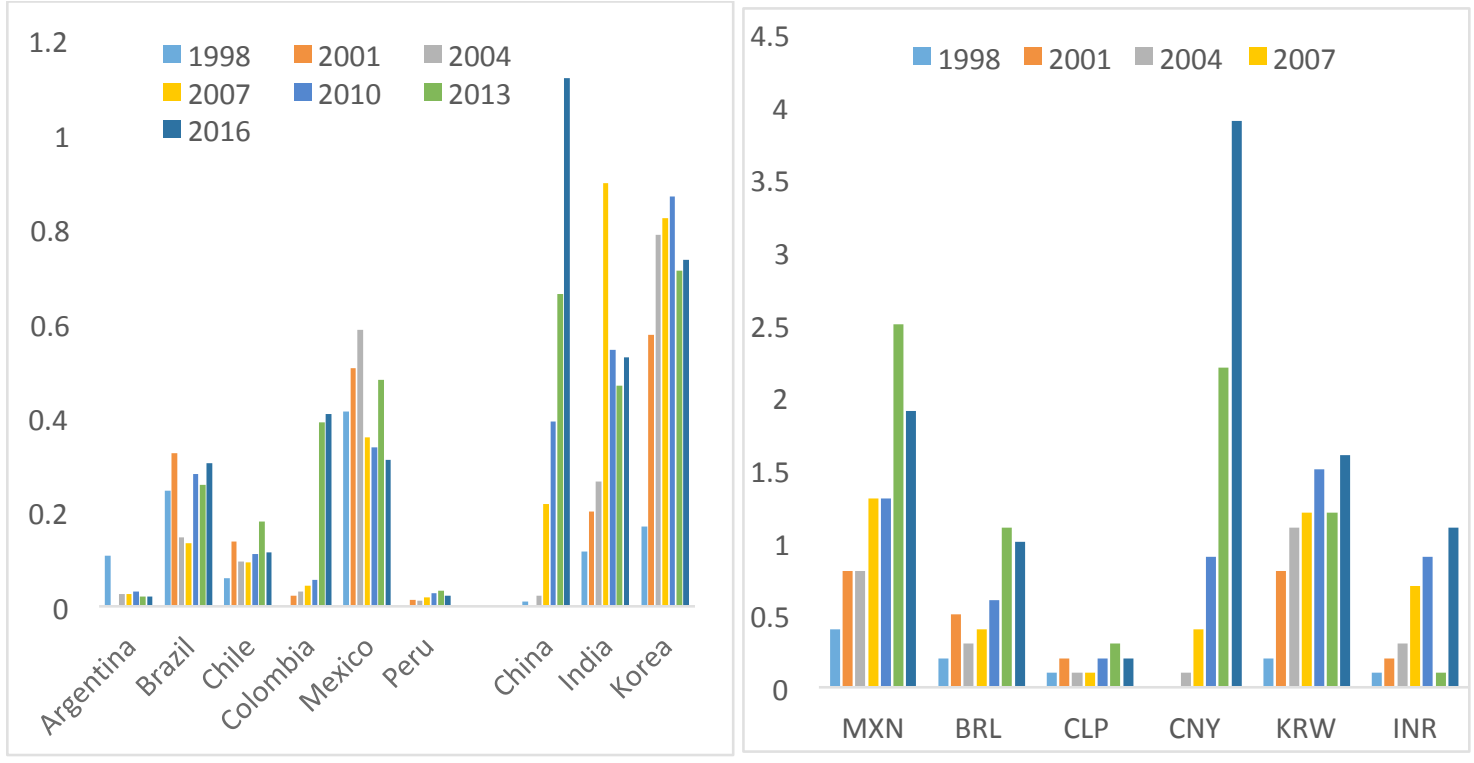

Source: Own calculation on data of BIS 2001, 2004, 2007, 2010, 2013, 2016.

In terms of the composition of instruments, in Latin America, except for Mexico, liquid transfers predominate, followed by installment transactions, where non-deliverable contracts are included, while in Mexico, exchange rate swaps dominate. Asia has a more diversified composition, with a balanced share between liquid transfers and exchange rate swaps, and lower volumes of installment transactions, which although considerable, decrease in the case of the Chinese exchange market (Table 2).

In terms of institutional counterparts, in Latin America, with the exception of Argentina and Brazil, the "informant dealers" dominate, particularly in Mexico with operations above $80 \%$ between 2010 and 2013, which could be explained by the "foreignization" of the banking sector. In second place are the "other financial institutions" highlighting their presence in Brazil, and in 2016 strengthening in Colombia, Mexico, China and India. The "nonfinancial clients" have a strong presence in all the countries analyzed, with the exception of Mexico and Korea, which would indicate that these economies have greater dominance by transnationals, with greater trade outside of their corporations.

Finally, the relationship between exchange transactions (in global terms, measured by net-net) with productive variables and external liabilities of the economies indicates financial market instability. The result is that exchange rate transactions related to the Mexican peso and the Brazilian real grew much faster, with respect to the Chinese renminbi (Table 3). This was due to the fact that Latin America opened up as a space for the valorization of transnational capital, especially after the crisis of 2008, and China went through a slower process of opening and higher productive expansion, thereby the internationalization of the Chinese renminbi was to influence the global financial market, with less dependence on external credits for its growth. 
Table 2. Forex by domestic financial centers (base gross-net) by location, institutional counterparties and type of instruments (\%)

\begin{tabular}{|c|c|c|c|c|c|c|c|c|c|}
\hline & \multicolumn{3}{|c|}{2010} & \multicolumn{3}{|c|}{2013} & \multicolumn{3}{|c|}{2016} \\
\hline & Local & $\begin{array}{c}\text { Cross } \\
\text { Border }\end{array}$ & & Local & $\begin{array}{l}\text { Cross } \\
\text { Border }\end{array}$ & & Local & $\begin{array}{l}\text { Cross } \\
\text { Border }\end{array}$ & \\
\hline Argentina & 85.5 & 14.5 & & 88.2 & 11.8 & & 94.3 & 5.7 & \\
\hline Brazil & 48.7 & 51.3 & & 58.6 & 41.4 & & 62.5 & 37.5 & \\
\hline Chile & 70.1 & 29.9 & & 72.6 & 27.4 & & 70.4 & 29.6 & \\
\hline Colombia & 82.3 & 17.7 & & 70.4 & 29.6 & & 75.7 & 24.3 & \\
\hline Mexico & 20.4 & 79.6 & & 25.0 & 75.0 & & 25.8 & 74.2 & \\
\hline Peru & 67.2 & 32.9 & & 84.6 & 15.4 & & 81.1 & 18.9 & \\
\hline China & 82.5 & 17.5 & & 83.8 & 16.2 & & 83.3 & 16.7 & \\
\hline India & 75.4 & 24.6 & & 72.7 & 27.3 & & 81.4 & 18.6 & \\
\hline \multirow[t]{2}{*}{ Korea } & 71.0 & 29.0 & & 67.7 & 32.3 & & 68.7 & 31.3 & \\
\hline & Spot & OF & FES & Spot & OF & FES & Spot & OF & FES \\
\hline Argentina & 98.1 & 1.9 & 0.0 & 96.4 & 3.6 & 0.0 & 98.7 & 1.3 & 0.0 \\
\hline Brazil & 62.0 & 27.0 & 2.1 & 44.3 & 37.2 & 2.9 & 37.7 & 44.3 & 0.9 \\
\hline Chile & 48.6 & 38.2 & 9.4 & 50.0 & 37.8 & 10.1 & 51.8 & 37.7 & 9.4 \\
\hline Colombia & 63.0 & 34.9 & 1.0 & 54.1 & 43.0 & 1.3 & 53.7 & 42.8 & 2.9 \\
\hline Mexico & 31.1 & 5.6 & 61.3 & 22.0 & 6.3 & 69.9 & 31.6 & 7.1 & 57.6 \\
\hline Peru & 71.4 & 27.0 & 1.1 & 73.6 & 22.4 & 3.1 & 54.0 & 21.1 & 18.1 \\
\hline China & 43.5 & 15.4 & 40.6 & 52.3 & 9.2 & 37.6 & 40.4 & 5.3 & 50.3 \\
\hline India & 49.0 & 17.9 & 28.1 & 49.5 & 12.0 & 35.7 & 43.7 & 13.2 & 40.2 \\
\hline \multirow[t]{2}{*}{ Korea } & 42.2 & 13.9 & 42.0 & 41.8 & 15.4 & 40.0 & 42.3 & 18.4 & 37.2 \\
\hline & ID & OIF & NFC & ID & OIF & NFC & ID & OIF & NFC \\
\hline Argentina & 17.5 & 21.6 & 60.9 & 17.5 & 21.6 & 60.9 & 25.6 & 10.0 & 64.4 \\
\hline Brazil & 38.1 & 42.2 & 19.7 & 38.1 & 42.2 & 19.7 & 23.0 & 49.6 & 27.4 \\
\hline Chile & 56.1 & 25.8 & 18.0 & 56.1 & 25.8 & 18.0 & 70.6 & 17.2 & 12.2 \\
\hline Colombia & 51.2 & 25.8 & 22.9 & 51.2 & 25.8 & 22.9 & 50.2 & 32.0 & 17.8 \\
\hline Mexico & 80.7 & 11.8 & 7.5 & 80.7 & 11.8 & 7.5 & 63.5 & 28.8 & 7.7 \\
\hline Peru & 62.3 & 14.0 & 23.7 & 62.3 & 14.0 & 23.7 & 57.3 & 14.1 & 28.6 \\
\hline China & 51.2 & 29.0 & 19.8 & 51.2 & 29.0 & 19.8 & 44.6 & 38.3 & 17.1 \\
\hline India & 61.8 & 8.6 & 29.6 & 61.8 & 8.6 & 29.6 & 44.7 & 35.4 & 19.9 \\
\hline Korea & 77.3 & 13.3 & 9.3 & 77.3 & 13.3 & 9.3 & 73.1 & 19.1 & 7.9 \\
\hline
\end{tabular}

Source: Own calculation based Bis, 2012, 2013, 2016.

The idea that exchange transactions in the currencies of emerging countries is not related to the expansion of output is reinforced. Between 2001 and 2016, Chinese daily GDP expanded by more than eight times, that of Brazil by three times, while that of Mexico barely increased by 1.4 points in relation to 2001. Thus, the relation between Forex transactions of emerging countries with internationalized currencies seems not to be related to the gross domestic product generated in each nation. In Mexico this ratio increased six times between 2001 and 2016, in Brazil it tripled, and in China it grew even more, as it was almost nonexistent at the beginning of the period (Table 3 ). 
The relation between Forex and the liberalization trade is not close, either. Mexico, the country with the one of the greatest trade liberalization, moved from 10.5 points in 2001 to 43.4 in 2016; Brazil, the country that opened up to trade least, tripled this coefficient for the same period; while in China, it only reached 17.8 points in 2016.

A measure of instability would be the Forex ratio based on the currencies of these emerging countries with their external liabilities, where Mexico has the highest coefficient, indicating that this is one route to greater access to international liquidity, though it also represents a great instability because if there is a change of opinion on Mexican macroeconomic variables or an event occurs independently of the country's economy, the liquidation of these foreign exchange transactions will lead to instability in the exchange rate and a drastic fall in international reserves, as happened between November 2016 and March 2017. Brazil has a lower coefficient, although it is multiplied by four times. The Chinese renminbi went from 0.8 to 302.1, an unprecedented increase, but the relationship between Forex and the Chinese renminbi and the external liabilities of the Chinese economy is lower.

Table 3. Forex indicators in terms of GDP, commercial oppennes and liabilities

\begin{tabular}{|c|c|c|c|c|c|c|}
\hline & 2001 & 2004 & 2007 & 2010 & 2013 & 2016 \\
\hline & \multicolumn{6}{|c|}{ Expansion FOREX, 2001=100 } \\
\hline Total Forex & 1.0 & 1.6 & 2.7 & 3.2 & 4.3 & 4.1 \\
\hline Forex MXN & 1.0 & 2.0 & 3.9 & 5.0 & 13.4 & 9.6 \\
\hline FOREX BRL & 1.0 & 0.9 & 2.2 & 4.6 & 10.0 & 8.6 \\
\hline \multirow[t]{2}{*}{ FOREX CNY } & 1.0 & 19.5 & 157.3 & 359.1 & 1253.5 & 2118.4 \\
\hline & \multicolumn{6}{|c|}{ GDP Expansion $2001=100$} \\
\hline Mexico & 1.0 & 1.1 & 1.4 & 1.5 & 1.7 & 1.4 \\
\hline Brazil & 1.0 & 1.2 & 2.5 & 3.9 & 4.4 & 3.2 \\
\hline \multirow[t]{2}{*}{ China } & 1.0 & 1.5 & 2.7 & 4.6 & 7.2 & 8.4 \\
\hline & \multicolumn{6}{|c|}{ Forex/GDP } \\
\hline Mexico & 5.1 & 9.6 & 13.7 & 17.3 & 39.1 & 33.9 \\
\hline Brazil & 3.8 & 2.8 & 3.4 & 4.5 & 8.7 & 10.3 \\
\hline \multirow[t]{2}{*}{ China } & 0.0 & 0.3 & 1.5 & 2.0 & 4.5 & 6.6 \\
\hline & \multicolumn{6}{|c|}{ Forex/X+M } \\
\hline Mexico & 10.5 & 17.8 & 24.0 & 28.5 & 60.7 & 43.4 \\
\hline Brazil & 14.5 & 9.6 & 13.6 & 20.2 & 34.6 & 42.5 \\
\hline \multirow[t]{3}{*}{ China } & 0.1 & 0.6 & 2.5 & 4.2 & 9.8 & 17.8 \\
\hline & \multicolumn{6}{|c|}{ Forex/Total liabilities } \\
\hline & 113. & & & & & \\
\hline Mexico & 9 & 262.8 & 269.2 & 240.7 & 490.1 & 585.4 \\
\hline Brazil & 83.8 & 217.4 & 38.7 & 50.5 & 166.6 & 352.9 \\
\hline China & 0.8 & 5.8 & 20.5 & 26.9 & 77.5 & 302.1 \\
\hline
\end{tabular}

Source: Own calculations based on World Bank and BIS data.

We can sum up this section stating that the Chinese renminbi and the Mexican peso share in common the increased volumes in foreign exchange transactions, differentiating in terms of financial counterparts, instruments compositions and more importantly, domestic financial center size. From where can be concluded that foreign transactions based in the Mexican peso and less so by other Latin American currencies (Brazilian real) are mainly cross borders, led by 'other financial institutions', whose purpose is to diversify their balance 
compositions, and obtain financial gains, unrelated to external transactions of commerce, finance, and debt restricting of the Mexican economy; moreover, Mexico's domestic financial centers are smaller. Thereby the success of the internationalization of the Mexican peso can be explained in terms of the insertion of the Mexican economy to the North America region.

While Forex transactions denominated in Asian currency, outstandingly the Chinese renminbi is headed by big institutions (informant dealers), much more related to the internationalization of the Chinese economic activity. In addition, cross-border activity is much more limited in terms of the size of the economy, and their domestic financial center is wider.

\section{Conclusions}

The financial system was drastically modified, with one of the main consequences being the deployment of money in its simplest and most basic form, which extends to the international financial market. Money appears as an eminently private, structurally endogenous debt in the financial market, which is distinguished by incurring in a process of globalization. A fundamental event in this process is the demonetization of gold, which removes all the vestiges of control over the money supply by central banks, circumscribing their function to determining the interest rate, with limited function of lender of last resort. In this context, the institutional arrangement of the financial market changes and the form of payments is modified.

The liquidity of the international reserve currency expands almost without limit, global currencies appear that are not international unit of reserves, outstandingly currencies of emerging economies, which are susceptible to be converted into international assets. The convertibility of global currencies (which are not international reserves) gives economies almost unlimited access to international reserves, in the upswing of economic cycles.

In this process, the role of the financial markets is modified. On the one hand, it is a source of financing especially for emerging countries with relatively weak and poorly integrated productive structures, which emit reduced finance in their own currency; accompanied by deep refinancing processes that transform debt between different currencies, extend deadlines and can even reduce the cost of debts. This process generates an increase in debts that does not always appear on balance sheets, especially when presented in net terms, which creates great financial instability. In turn, the exchange markets are activated, which are a source of risk reduction, but so too are highly unstable financial innovations, leading to the conclusion that not all financing is speculative but nor is it free of financial instability either.

The opening up of financial markets takes place in a context of trade liberalization with major imbalances in the current and financial account. From the experiences of Latin America and Asia, we can indicate that two currencies clearly become international assets: the Mexican peso and the Chinese renminbi. From our perspective, these processes correspond to two different strategies. Mexico, in the context of its access to the rest of North America, acquires greater credibility and its currency is used to diversify the balance sheets of non-banking financial institutions; while China in its process of internationalization on the basis of economic growth seeks to influence international markets. 


\section{References}

Avdjiev, S.; McCauley, R. and Shin, H. (2015) "Banking free of the triple coincidence in international finance", BIS Working paper, n.534.

Gutiérrez, E.; Bernardino, A. and Gutiérrez, J. (2014) "La evolución del mercado global de divisas y su situación en el contexto de la crisis financiera", Boletín Económico de ICE n.3049, p. 3-14.

BIS (2001) Triennial Central Bank Survey, Foreign exchange and derivatives market activity in 2001. Statistical Annex Tables. Available at https://www.bis.org/publ/rpfx02t.pdf. Accessed on 13/08/2018.

BIS (2004) Triennial Central Bank Survey Foreign exchange and derivatives market activity in 2004. Statistical Annex Tables. Available at https://www.bis.org/publ/rpfx05t.pdf. Accessed on 13/08/2018.

BIS (2007) Triennial Central Bank Survey Foreign exchange and derivatives market activity in 2007, Statistical Annex Tables. Available at https://www.bis.org/publ/rpfxf07t.pdf. Accessed on 13/08/2018.

BIS (2010) Triennial Central Bank Survey. Report on Global Foreign Exchange market activity in 2011. Available at https://www.bis.org/publ/rpfxf10t.pdf. Accessed on 13/08/2018.

BIS (2013) Triennial Central Bank Survey. Global foreign exchange market turnover in 2013. Tables revised, published in February 2014. Available at https://www.bis.org/publ/rpfxf13fxt.pdf. Accessed on 13/08/2018.

BIS (2016) Triennial Central Bank Survey, Foreign exchange turnover in April 2016. Tables revised September 1st. 2016. Available at https://www.bis.org/publ/rpfx16fx.pdf. Accessed on 13/08/2018.

Borio, C and Disyatat, P. (2015) "Capital flows and the current account: Taking financing (more) seriously", BIS Working Papers, n.525.

Bossone, B. (2003) "Thinking of the Economy as a circuit" in: L-P. Rochon and S. Rossi (eds.) Modern Theories of Money: the nature and role of money in capitalist economies, Cheltenham, UK; Northhampton, US: Edward Elgar, p. 142-172.

Cepal (1949 [1998]) "Estudio Económico de América Latina" In: R. Bielschowsky (org.), Cincuenta Años de Pensamiento en la Cepal: textos seleccionados, v.1, Santiago, Chile: Fondo de Cultura Económica-Cepal, p.131-172.

Chang, H-J. and Grabel, I. (2004) Reclaiming development, London and New York: Zed Book Ltd., p. 135-139.

De Cecco, M. (2012) "Global imbalances: past, present, and future", Contributions to Political Economy, 31(1), pp. 29-50.

Eatwell, J. and Taylor, L. (2000) Global finance at risk: the case for international regulation, New York: The New Press.

Epstein G. (2005). Financialization and the world economy, Cheltenham, U.K.: Edward Elgar Publishing.

Graziani, A. (2003) The monetary theory production, Cambridge, UK: Cambridge University Press. 
Harvey, J. (2009) "Currencies, Capital Flows and Crises: a post-Keynesian analysis of exchange rates, New York: Routledge.

Kalecki, M. (1971) Selected essays on the dynamic of capitalist economies: 1933-1970", Cambridge, UK: Cambridge University Press, p. 110-123.

Kaltenbrunner A. and Panceira, J. (2017) "Subordinated financial Integration and Financialisation in Emerging Capitalist Economies: The BrazilianExperience" New Political Economy, 23(3), p. 290-313. DOI: 10.1080/13563467.2017.1349089

Keynes, J. (1936 [1964]) The general theory of employment, interest, and money, Orlando, FL.: Harvest Book, Harcout Inc.

Krugman P. and Obstfeld, M. (2006 [1998]) Economía Internacional: Teoría y Política, Madrid: Pearson Education.

Levy N. (2016) "Latin American in the new international order: new forms of economic organizations and old forms of surplus appropriation" in: N. Levy and E. Ortiz (eds.) The financialization response to economic disequilibria: European and Latin Amercian Experiences, Cheltenham, UK: Edward Elgar Publishing Limited.

Levy, N. and Domínguez, C. (2016) "The operation of the Mexican banking system under foreign multinational corporations control: New activities and traditional income", International Review of Applied Economics, 30(4), p. 527-546.

Levy, N. (2018) "La crisis de la financiarización en américa latina: ¿Fin del modelo de acumulación liderado por las exportaciones? In: N. Levy (ed.) Financiarización y crisis de las estructuras productivas en países en desarrollo, Facultad de Economía, Universidad Nacional Autónoma de México, Mexico City.

Lipscomb, L. (2005) "An Overview of Non-Deliverable Foreign Exchange Forward Markets" Federal Reserve Bank of New York, Available at https://www.bis.org/publ/cgfs22fedny5.pdf. Accessed on 13/08/2018.

Minsky, H. (1986) Stabilizing an unstable economy, New Haven: Yale University Press.

Minsky, H. (1989) "Financial structures: indebtedness and credit” In: A. Barrere (ed.) Money, credit and prices in a Keynesian perspective, New York: St Martin's Press, pp. 49-57.

Moreno-Brid, J. and Garry, S. (2015) "Economic performance in Latin America in the 2000s: recession, recovery, and resilience?" Oxford Development Studies, 44(4), p. 384-400, DOI: 10.1080/13600818.2015.1127907

Mundell, R (1961) "A theory of optimum currency areas" American Economic Review, 51(4), pp. 657-665.

Ortiz, E. (2016) "The limits of the export led growth model: The Mexican case" In: N. Levy and E. Ortiz (eds.) The financialization response to economic disequilibria: European and Latin Amercian Experiences, Cheltenham, UK: Edward Elgar Publishing Limited.

Rodrik, D. (2015) “Premature Deindustrialization, NBER Working Paper, n.20935, Available at http://www.nber.org/papers/w20935. Accessed on 13/08/2018.

Russell, E. (2008) New Deal banking reforms and Keynesian welfare capitalism, New York: Routledge.

Sawyer, M. (2016) "Graziani's analysis of the circuit: does it extend to the era of financialisation?" Review of Keynesian Economics, 4(3), pp. 303-315. 
Seccareccia, M. (2003) "Pricing, Investment and the Financing of Production within the Framework of the Monetary Circuit: Some Preliminary Evidence", In: L-P Rochon and S. Rossi (eds.) Modern Theories of Money, Cheltenham, UK: Edward Elgar Publishing Ltd., pp. 173-197.

Seccareccia, M. (2012/2013) "Financialization and the Transformation of Commercial Banking: Understanding the Recent Canadian Experience before and during the International Financial Crisis." Journal of Post Keynesian Economics, 35(2), pp. 277-300.

Stalling B. and Studart, R. (2006) Finance for development: Latin America in comparative perspectives, Washington, DC: Brookings Institution Press.

Toporowski, J. (2000) The end of finance: capital market inflation, financial derivatives and pension fund capitalism, New York: Routledge.

Toporowski, J. (2012) "Overcapitalization", In: j. Toporowski and J. Michell (eds.) Handbook of Critical Issues in Finance, Cheltenham, UK: Edward Elgar Publishing Ltd, p. 207-273.

Toporowski, J. (2017) Lectures for the Department of Economics, University of Bergamo, mimeo, March-April. 